\title{
REPORT OF THE SUB-COMMITTEE ON SURVEYS
}

$\mathrm{N}^{\circ}$

O FORMAL meetings of the Sub-Committee were held during 1937, but through the efforts of the members considerable advance has been made in air photographic surveys.

Eight additional strips of verticals were taken of the 10-mile experimental area at Petawawa, making 26 in all which have been made at various seasons from various heights, with various films and filters, and vertical and oblique.

Three were taken on March 13th, while the snow was on the ground, from about 7,500 feet, using Stereo-green and Aero No. 2 filters. The Stereo-green was the best. These showed the distinction between softwoods and hardwoods better than summer photos.

One was taken on March 24th from 1,430 feet, with Stereo-green filter but the scale was too small for satisfactory tree measurement.

Four were taken on May 11th, after the snow had melted and before the deciduous leaves were out. This proved to be the only photographic day that spring, when these conditions could be secured. These were taken from 11,400 and 8,000 feet, using Stereo-green and Aero No. 2 filters. The former were too small a scale and the latter were not very sharp. The Aero No. 2 filter gave the best results.

The results of these experiments can be seen at the Exhibit.

The Dominion Forest Service conducted a working plan survey of the Riding Mountain National Park, covering 1,196 square miles. Vertical photographs taken eight years previously did not show the recent cuts and burns and lacked detail for type classification and volumetric estimates, so Canadian Airways Limited took a set of steep obliques in March, while the snow was on the ground. They were taken from 10,000 feet with a 12inch lens and though the scale was smaller than is desirable, the photographs were satisfactory.

The forest types were delineated and volumetric estimates prepared for the areas carrying merchantable timber. This data was supplied to a field party who checked the aerial estimates and found them remarkably accurate. The field party also secured increment data and completed the working plan survey in October, which constitutes a record for this class of survey. 
The cost of the photographic survey per square mile was as follows:

$$
\begin{array}{lr}
\text { Steep oblique photography } \ldots \ldots \ldots \ldots \ldots \ldots \ldots & \$ 4.50 \\
\text { Interpretation of forest data } \ldots \ldots \ldots \ldots \ldots \ldots \ldots & .52 \\
\text { Transfer to Map } \ldots \ldots \ldots \ldots \ldots \ldots \ldots \ldots \ldots & .09 \\
& \\
& \$ 5.11
\end{array}
$$

In addition there was some unknown expense for draughting, planimetering etc., such as is necessary in any mapping, whether from air or ground surveys.

The steep obliques were taken with a single camera and the cost would have been greatly reduced if a tri-camera mount had been available.

The cost of the field work was approximately $\$ 2.60$ per square mile, which showed a very considerable saving, due to the use of the photographs. Volumetric estimates have been made on thousands of square miles of timberland in connection with the forest inventories in Saskatchewan and Nova Scotia, and smaller special projects in Quebec, Ontario, Alberta and the Northwest Territories.

The double-vision projector designed by Mr. H. E. Seely has proved of great assistance in transferring data from the photographs to a map. Seven of these instruments have been manufactured for governmental and private use.

A precise model is being constructed for this purpose by the Bausch and Lomb Optical Company for the Forest Service. In this instrument artificial control is provided by means of grids inserted in the eye pieces which are equipped with special lenses. The scale can be enlarged or reduced.

The use of air photographs has now become an established feature in the forestry departments of a number of operating companies.

Mr. F. R. Wilcox and Mr. L. Martineau presented an excellent paper on the Use of Vertical Photographs at the Summer Meeting of the Canadian Pulp and Paper Association, which was published in the October issue of the Pulp and Paper Magazine.

The Sub-Committee joined with the Canadian Institute of Surveying in securing Mr. Leon T. Eliel, Vice-President, and Mr. R. G. Sanders, Photogrammetrical Engineer, of Fairchild Aerial Surveys Incorporated, to address the annual meetings of the Institute in Ottawa on February 3, 1938. 
The members of the Canadian Society of Forest Engineers are invited to attend these meetings.

\section{DISCUSSION}

In reply to a question by $\mathrm{Mr}$. Ellis, Mr. Craig stated that the cost of aerial mapping in previously unphotographed territory would be $\$ 50$ to $\$ 70$ per square mile. 